\title{
Visual Translation of Guru Nanak's Philosophy by Janamsakhi Illustrators
}

\author{
Gurdeep Kaur \& Rohita Sharma \\ Department of Business and Fine Arts, Lovely Professional University, Phagwara, Punjab, \\ India. Email: gurdeepkaur121@yahoo.in.
}

Received July 13, 2017; Revised September 25, 2017; Accepted September 28, 2017; Published October 12, 2017.

\begin{abstract}
From the second half of seventeenth century, the people of undivided Punjab started to appoint illustrators to draw the manuscripts of Guru Nanak's life stories. The main purpose of illustrating the manuscripts was to understand and convey the Nanakian Bani and worship the Guru through the miniature visuals preserved at home. Janamsakhi texts and bani of Guru are also the rich source to understand northern Indian culture and society of fifteenth century. The paper attempts to link Guru Nanak's life and bani with the miniature visuals to reread the illustrators' interpretations merged with their own imagination and perceptions. The study concludes that the Janamsakhi illustrations are the amalgamation of various facts and fusions of cognitions and perspectives of different illustrators.
\end{abstract}

Key Words: Guru Nanak, Janamsakhi illustrations, illustrators, philosophy, Sikhism

Religion always inspires the arts and to paint divinities is common and universal human behavior. Often people want to see a glimpse of their God. This desire inspire the painters to paint religious themes. "....a painted figure is the equivalent of its subject. It not only has "a life of its own," it has the subject's own life.' (Archer 1960, 11). Sikhism also presented themes for visualization. Guru Nanak's narrative are popular as Janamsakhis (birth stories), which are of various versions like Bala, Meharban and Puratan (old) Janamsakhi penned during different times, so these works are of some variations. But one thing is common in these texts that Guru Nanak was a true philosopher, who travelled his whole life to seek the distinctions of different faiths of the world and contributed his own philosophy to the Sikhism in the form of bani (words). Guru Nanak's entire bani praises the formless and universal God and rejects the meaningless traditions and rituals which come in the way of salvation in his Jap ji, Aarti, Baramaha including the representation of contemporary society in Sidhgosht, Baburvani and Asa di vaar.

Along with Guru Nanak's bani, some common stories of him remained popular among Sikh community for a long period. Illustrators perceived those assumptions and visualized in their work. The paper attempts to find that how Guru Nanak faced the society of multi- cultural traditions to spread his philosophy and how illustrators perceived these events and visualized in their work. What were the popular sakhis, which inspired much the Janamsakhi illustrators and how various illustrators represented multicultural society in Janamsakhi illustrations of different styles. The whole study seeks the answers of the above questions. Although Guru Nanak rejects the ritualism and idol worship and focuses the name (Naam) of 'Formless and Immortal One'

(c) AesthetixMS 2016. This Open Access article is published under a Creative Commons Attribution Non-Commercial 4.0 International License (http://creativecommons.org/licenses/by-nc/4.o/), which permits non-commercial re-use, distribution, and reproduction in any medium, provided the original work is properly cited. For citation use the DOI. For commercial re-use, please contact editor@chitrolekha.com 
during his whole life but the practice of portraiture of Guru to worship him like a God is against Sikh concept of worship. But perhaps, people wanted to see their Guru in spiritual texts, as in India, it is a common practice to portray divinities in manuscripts.

There are various illustrated manuscripts of Janamsakhi of about seventeenth- nineteenth centuries preserved at various museums. The work of illustrating Janamsakhis started in the second half of seventeenth century. The first dated manuscript with twenty nine illustrations is of 1658 (Chaitanya 1994, 9) which was the time of Guru Har Rai ji (1645-61), the seventh Sikh Guru. Second dated manuscript with forty two illustrations is of 1724 in the family collection of Bhai Arduman Singh at Bagharian in Patiala (Kaur Singh 2013, 32). ${ }^{1}$ The most popular and noteworthy illustrated Janamsakhi manuscript is B-40 (B-40 is its accession number) Janamsakhi at the India Office Library (Hans 1987; Stronge 1999, 209) of 1733 A.D. (figures 2, 14, 15, 16 and 17) with 57 illustrations. Another significant leafs as 'unbound set' of forty- one Janamsakhi illustrations is in Asian Art Museum (Museum no.1998.58.1- 1998.58.41) (figures 4, 5, 6, 7, 9, 10, 11, 12, 13, 18 and 19). Government Museum and Art Gallery also preserved Janamsakhi leafs and sketches (figures 1, 8) of Pahari style and painted manuscripts. The study centers the three series of illustrations in which B-40 series, Asian Art Museum series and the series of sketches preserved at Chandigarh Museum are included. 'The narratives portray the divine dispensation of their founder and his (Nanak's) concern for kindness, social cohesiveness and divine unity.' (Stronge 1999, 33).

The illustrators of Janamsakhis elected stories to paint which were popular among Punjabi populace, but their perception and thematic representation are different. All series of Janamsakhi illustrations are painted in sequential way to make the stories understandable. Janamsakhi texts start with the birth of an infant. The first divine glimpse of the baby was seen by 'Daulatan' the midwife. But the visualization of birth of child Nanak is a rare theme with the illustrators. The illustrator of B-40 manuscript did not paint the birth event of guru, while Pahari painter sketched the theme of birth. In figure 1 ; baby Nanak is in the hands of his father; Mehta Kalu Khatri and mother Mata Tripta or mid-wife is standing behind him. All the figures are visualized in popular Pahari court attires, practiced by the Hindu painters.

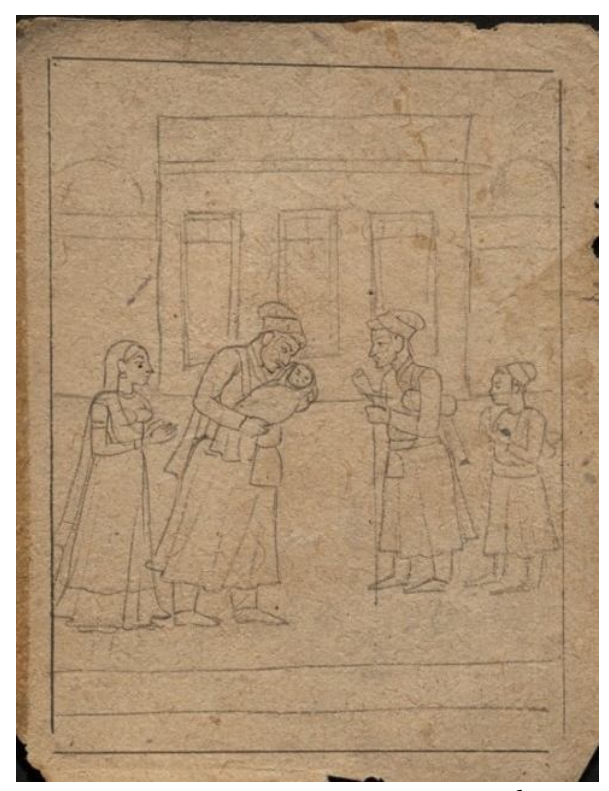

Figure 1. Birth of Guru Nanak Dev, Sikh-Guler. Middle/last quarter of $18^{\text {th }}$ century AD, P.K. Kapoor, Acc.no. 2307, Courtesy: Government Museum and Art Gallery, Chandigarh. 
A solid form of architecture with three windows is drawn to make background heavy and solid as to represent stability at the moment of birth of a newborn. Three open windows are perhaps for the depiction of three worlds. Inside the house, people started to enter to see their new trendsetter. Surprised midwife was also trying to say something with her raised hand and open eye. Pahari painters were habitual of Vaishnava themes and it was not new to them to paint the birth of Lords Krishna and Rama.

We dissolve in the world of imaginations to see the courageous and miraculous deeds of baby Krishna as well as his romance with Radha and gopis, but when we see child Nanak, an earthly world comes in front of our eyes. Child Nanak goes to learn Sanskrit as well as Persian and Arabic. The representation of various cultures begins with the interaction between child Nanak and his teacher Brahmin pundit Hardayal, from whom he went to learn Sanskrit and grammar. The illustrator of B-40 manuscript represents Brahmin teacher 'Padha" (Singh 2004, 57) in a traditional Hindu dress of yellow (figure 2). As Nanak was born in a Hindu Kshtriya family, he is also appearing in yellow and saffron with a wooden tab holding in his hand, which resemble with the intellectual of his teacher, in front of whom he uttered the divine poem of divine alphabet, 'patti (tab) likhi (penned) (SGGS, Mehl 1, 432-434), while other pupils are involved in daily work. Guru Nanak always portrays different from known Hindu- Muslim saintly figures. Illustrators portrayed him with Hindu- Muslim signs to give him a distinct cognizance. As fifth Guru says, 'na hum hindu (we are neither Hindu), na musalmaan (nor Muslim).' (SGGS, Mehl 5, 1136)

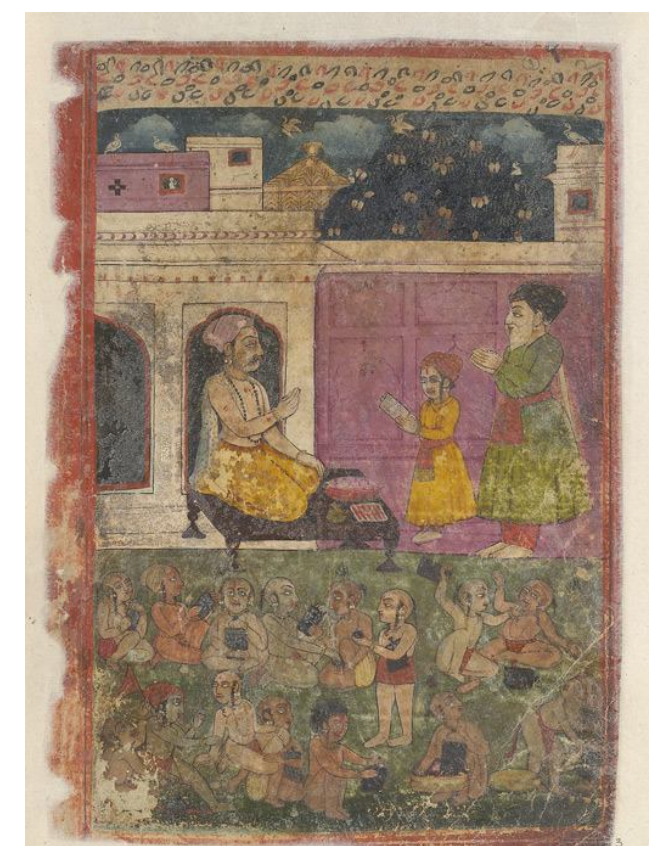

Figure 2. Father Kalu takes Baba Nanak to School. 1733. B-4o Janamsakhi. India Office Library. Source: http://www.bl.uk/onlinegallery/onlineex/expfaith/sikhmanu/babananak/largeimage74063.html

Another school scene (figure 3) is visualized with other concept by another illustrator, who perceives child Nanak to go to learn Persian by a Muslim teacher, Mullah Qutab-ud-din. Painter of figure 3, (a rare leaf preserved at Victoria and Albert Museum), perceives this scene with his own imaginations, where teacher appears in blue Muslim attires and a typical Muslim turban which indicates that he is a Muslim. Although child Nanak stated these words to see Muslim teacher, 'Yak araj guftam pesi to dar gos kun kartar. Haqa kabir karim tu baeaib parvadgaar. Duneeya mukamein faani tehkeek dil jaani. Mum sar mooe ajrail girfteh dil hech na daani' (SGGS, Mehl 1, 721) but in the scene, illustrator's own imaginations worked and child 
Nanak is mistakenly touching his feet which is not a Muslim practice. The illustrator divided surface to create two events in two moments, in which Mehta Kalu with his son is leaving the room after joining the child Nanak for school in the upper background, while in front ground, the illustrator opens a world of contemporary society for the spectators, where regular events are happening in a school room. In figure 3, the group of pupils represents a clearer image of social structure where Persian was the language of account and documents while in figure 2, mostly pupils are appearing with clean shaved heads, which is a Hindu practice and depicts that Sanskrit was learned only by Hindu high class society. The representation of boy Nanak in figure 2 appears divine but in figure 3, it appears earthly as against standing above the land in figure 2 . The differences of attires of two teachers from two communities defines two cultures while the visual translation of same theme by two illustrators of different mind-setup also represent two different perspectives for two languages and their learners.

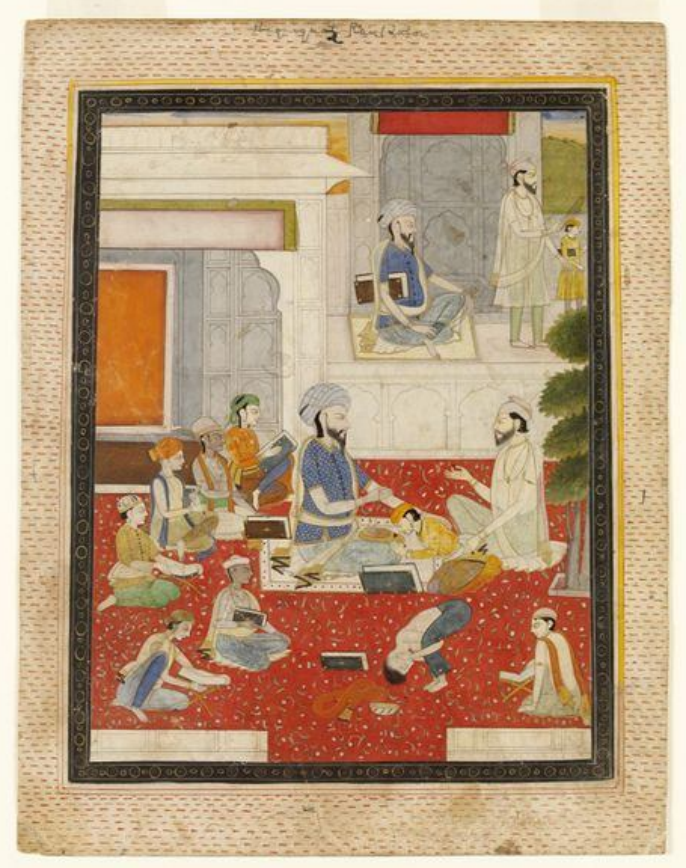

Figure 3. Guru Nanak at school. C. 180o-1810. Museum number- IS.20-1952. Victoria and Albert Museum. Source: http://collections.vam.ac.uk/item/069364/painting-unknown/

When child grew, he started to grasp the world around him. Boy Nanak observes the rituals of his family and he disobeys the suspicious and meaningless rituals with double meanings. A child's kind and innocent heart wants to walk on the simple but tough path of equality and charity to serve the human being, so he does sacha sauda (true bargain), in which he feeds the hungry Brahmin Sant Ren and his followers with the money, given by his father to invest in the trade. Guru Nanak's philosophy of charity and community kitchen is the base of Sikhism in which everyone is equal, socially or economically in the dynasty of God till today. The whole world and all creatures are of God. The illustrator depicts great philosophy with minimal colours and simple forms in figure 4. Sant Ren accompanying his followers sitting around and conversing with child Nanak reflects the beginning of amalgamation of two concepts, in which one is of cindered bodies, long hair and minimal clothing of sadhus involved in yogic practices represent a symbol of renunciation of worldly attachment while to communicate the philosophy of child Nanak in four directions, illustrator set the figure of boy with folded hands and nimbus around head is like an altruistic, amiable (like his name Nanak or na + nak literally who has not nak or nose, 
emblematically ego) in centre as a flame of knowledge which denotes the child as Jagat Guru (teacher of the world). A green flat background is a symbol of cultivation, and also symbolizes the satisfaction the needy persons and cools the eyes of spectators. The illustrator also tries to connect the two different concepts of life to link saffron coloured minimal clothing of sadhus with child's saffron cloths, which also balances the illustration.

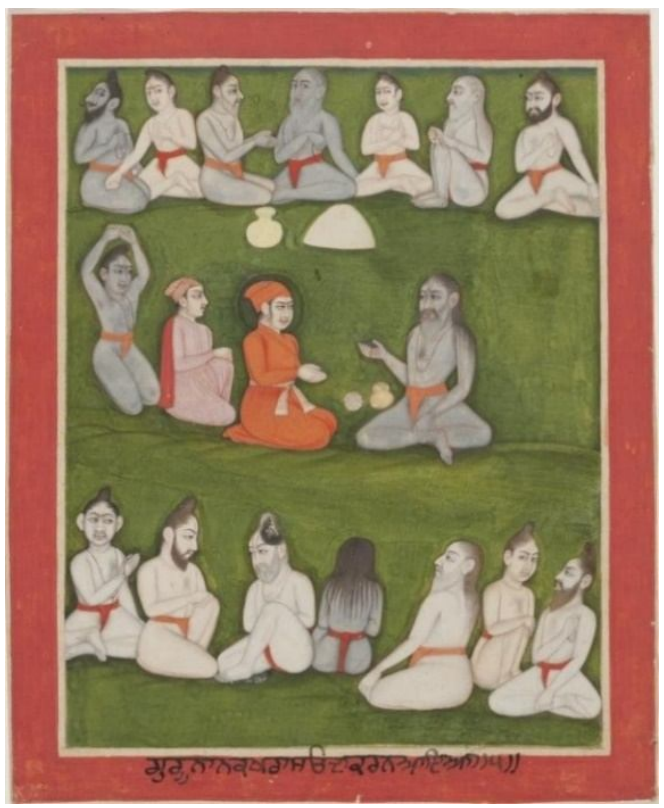

Figure 4. Guru Nanak and the holy man Sant Ren. C. 1750-18oo. Probably Murshidabad, West Bengal state. Object ID: 1998.58.4. Asian Art Museum. Source:

http://searchcollection.asianart.org/view/objects/asitem/search@/59?t:state:flow=fo211cbo-b2db-43eb-9085di8c98cfa 774

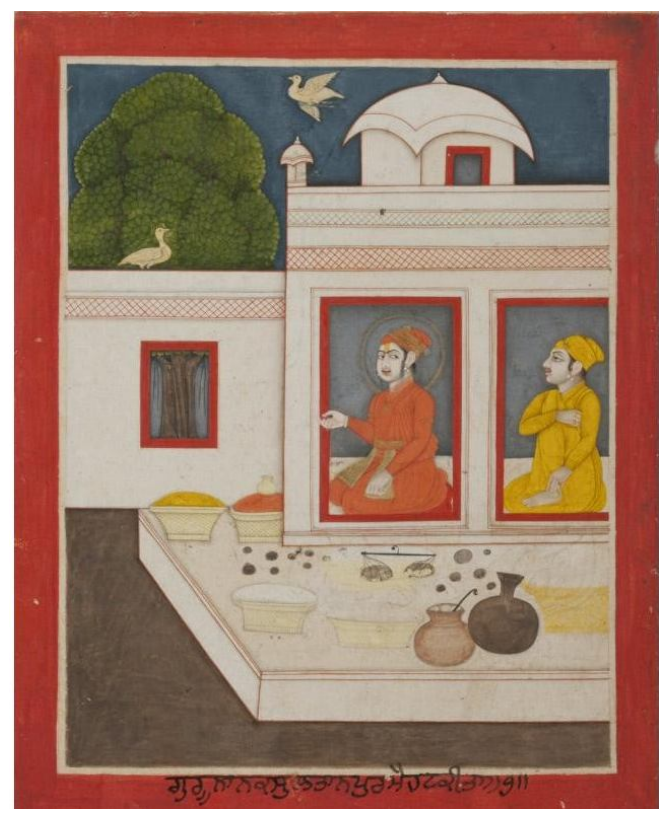

Figure 5. Guru Nanak in the provision house. C. 1800-190o. Pakistan, Lahore. Object ID: 1998.58.6. Asian Art Museum. Source: http://searchcollection.asianart.org/view/objects/asitem/search@/59?t:state:flow=fo211cbob2db-43eb-9085-d18c98cfa774 
In his young age, Guru Nanak was employed to manage a provision house of local ruler in his brother-in-law's town, where he served all his earned money for the benefaction of sadhus and fakirs. In figure 5 , as a young boy, he is shown seated in an orange door-frame against grey coloured wall, wearing orange attire with a golden halo around his head with a hand raised to communicate his message of devotion. Perhaps his hand is raised out of the frame to do charity. Accompanying figure in yellow inside a different frame with locking hands is to assistance Guru in his great task but illustrator also represents the mind setup of a common earthly man with the medium of second figure with locking hands, who with his unsatisfied worldly desires always hesitates to donate his whole to the penurious and in actual, through the figure of Maradana, lifelong companion of guru, illustrator wants to interpret this worldly truth, who always remained with Guru but didn't satisfy his soul while Guru's hands always raised to donate his whole to the world. All the vessels and containers are full of grains, which are also the symbol of prosperity and eternity. The influence of charity can be seen in the pleasant atmosphere where chirping cranes on white architecture and full grown green tree are seen as symbolic equipment of illustrator's imaginations.

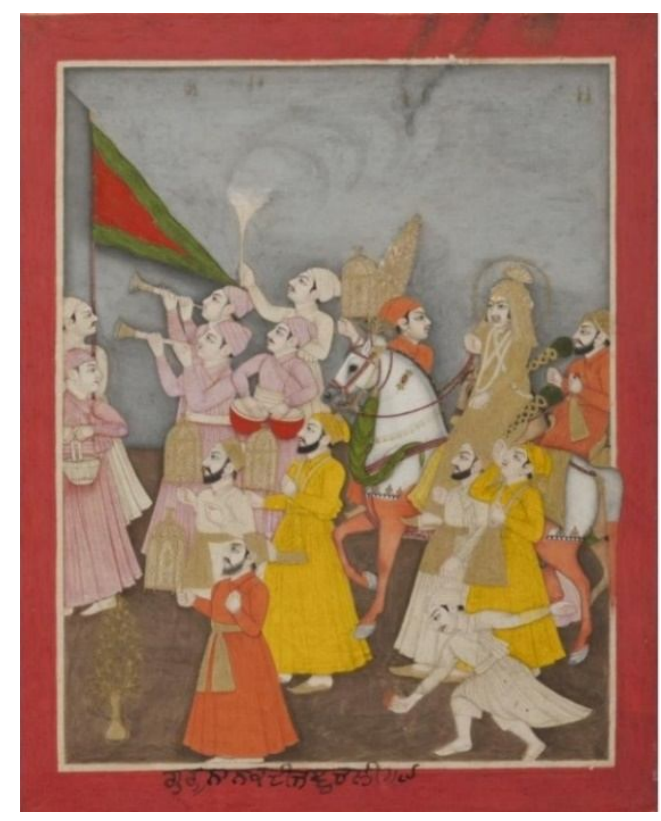

Figure 6. Guru Nanak's wedding procession. C. 180o-190o. Pakistan, Lahore. Object ID: 1998.58.8. Asian Art Museum. Source: http://searchcollection.asianart.org/view/objects/asitem/search@/63?t:state:flow=e35029195d6e-46a9-95b2-6c21e997с6еa

To communicate the message of Grihasta (household), young Nanak of twelve was engaged with Sulakhni of Batala, daughter of Mool Chand patwari. Why the composition of marriage of a saintly figure is so thriving in figure 6, while Nanak is always represented in yellow or safforn? The answer is that, the views of Guru Nanak about marriage and worldly relations are favourable. He was not in favour of the ancient Hindu- vedic philosophy of four ashrama (age based life stage, Brahmacharya (student), Grihastha (householder), Vanaprastha (retired) and Sannyas (renunciation) but he also utteres his philosophy about grihasta 'Na bahina (neither sisters) bharjaiya (nor sister-in-laws) na se sasureeyah (nor the mothers-in-law, shall persist)' (SGGS, Mehl 1, 1015) that we should detached this immortal world, where nothing is stable.

Although Guru Nanak, born in Hindu family, also spent his whole life as an ascetic, but he was in favour of Grihastha (household) only. If the whole world becomes ascetic, then who will feed them. The picturization of the marriage of a handsome groom in golden attire accompanying 
prosperous Bedi family is successfully done through the illustrator. In figure 6, Barat or wedding procession of Bedis is leading towards Batala from Sultanpur in Punjab, in which young Nanak is portrayed in golden dress, mounted on a hina dyed stallion and others are in saffron, yellow and white, dancing and enjoying the pleasing moments of 'barat of jagat guru' as a halo around his head depicts him as a distinct character in the world. Group of musicians playing instruments and carrying torches in pink accompanying the procession to create a musical atmosphere. A saffrongrren pataka is also a symbol of divine

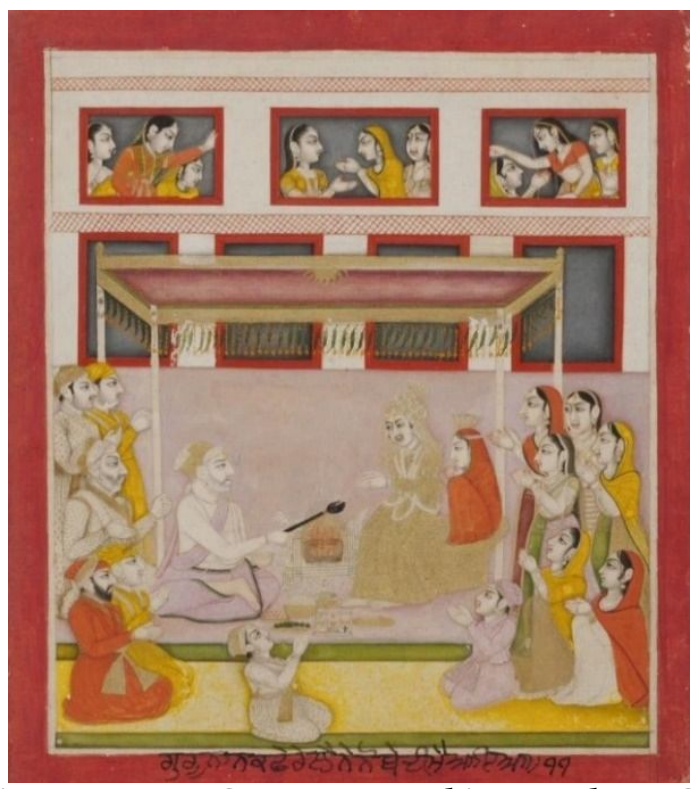

Figure 7. Guru Nanak's wedding ceremony. C. 180o-19oo. Pakistan, Lahore. Object ID: 1998.58.9. Asian Art Museum. Source: http://searchcollection.asianart.org/view/objects/asitem/search@/64?t:state:flow=e35029195d6e-46a9-95b2-6c21e997c6ea

Although Nanak was against ritualism, so refused to do marriage rituals. Nanak set with Mata Sulakhni on a plateform against a mud-wall for marriage. An old lady warned Nanak that wall could damage. But Nanak said that it cannot damage for centuries. It is preserved at Gurudwara Kandh (wall) Sahib at Batala, where Nanak got married. Illustrator portrayed Guru Nanak involved in marriage rituals as par Hindu caste sitting against a mud wall. In figure 7 , young Nanak and his betrothed are involved in Hindu marriage ritual of yaga under a goldenpink royal canopy while acompanying intimates are blessing newly wedded couple.

In figure 8 , he is with his two sons, Sri Chand and Lakhmi Chand, which is a very rare theme to paint. He is shown as an ascetic indifference towards the worldly substances while two boys are with their mother Mata Sulakhni resting on a cot in front of architecture. Two trees and outside area compile the background for Nanak to represent his apathy towards the world. The painting reminds the holy family of Shiva- Parvati which was often portrayed by Pahari illustrators. When we see the setting of the painting (figure 8), it can be divided into three parts, where one is of Mata Sulakhni and younger son Lakhmi Chand playing in the lap of his mother. Second part contains the elder son of Guru Nanak; Sri Chand, whose upbringing was done by Bibi Nanaki, the elder sister of Guru Nanak, and lately he founded the Hindu ascetic sect of Udasi, which creates a link between ascetic and households, where wife Sulakhni is a symbol of households and Guru Nanak was an ascetic. The younger son of Nanak was brought up by his wife and the attachment of younger son with his mother is clearly depicted by the Pahari illustraor. And the third part depicts Guru Nanak and his attachment with his elder son, Sri Chand. 'Babaji (Sri Chand) was in 
one sense Guru Nanak Dev ji's first disciple.'3 Although he was also an ascetic but he was also in favour of grihastha or households as to raised his brother's son as his own son; Baba Dharam Chand. ${ }^{4}$ Guru Nanak himself asks the siddhas; Sidhgosht, 'Kis karan (why) grihu (house) tajiyo (left) udasi (itinerant Udaasee). Kis karan (why) ehu bhekh (disguise) nivasi.' (SGGS, Mehl 1, 939).

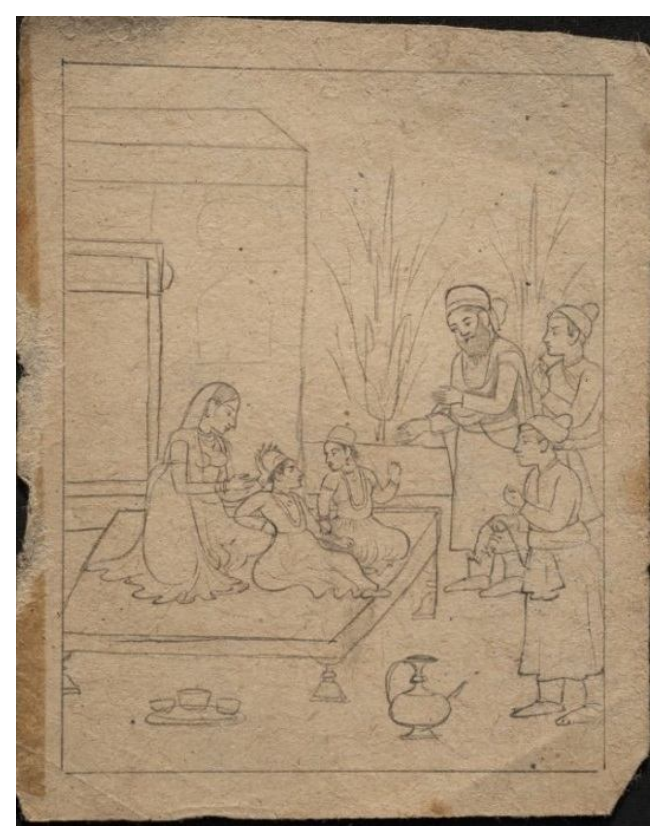

Figure 8. Guru Nanak with his sons Siri (Sri) Chand and Lakshman (Laxmi/ Lakhmi) Chand. Sikh-Guler. Middle/last quarter of $18^{\text {th }}$ century AD, P.K. Kapoor, Acc.no. 2310, Courtesy: Government Museum and Art Gallery, Chandigarh.

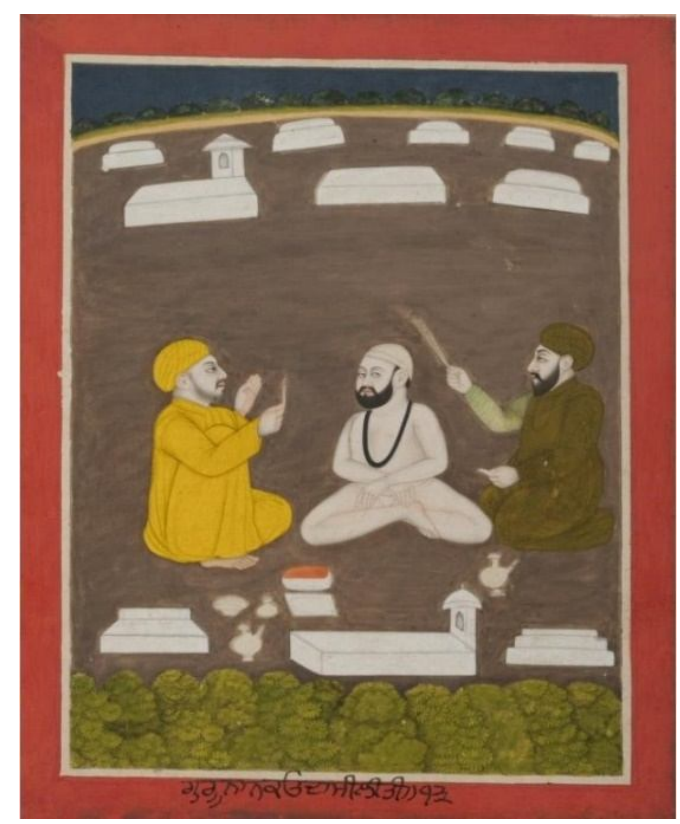

Figure 9. The ritual treatment of Guru Nanak. C. 180o-19oo. Pakistan, Lahore. Object ID: 1998.58.12. Asian Art Museum. Source: http://searchcollection.asianart.org/view/objects/asitem/search@/67?t:state:flow=e35029195d6e-46a9-95b2-6c21e997c6ea

Guru Nanak's philosophy is against the ritualism and polytheism. Figure 9 is just against the Hindu culture in which Nanak is seen in a graveyard after pleasant experiences of his marriage 
ceremony. Why Nanak is shown like a Muslim in graveyard just after his marriage? After marriage young Nanak came back to Sultanpur where he donated his all earned money to the fakirs. Nanak became questionable among the orthodox society. He was taken to graveyard for ritual treatment. A mullah kindling heave and smoke aroused to Nanak. Mullah asked Nanak about him and he answered, 'Koi (some) aakhe (call) bhootna (ghost) ko kahe (call) baitala (demon). Koi aakhe (some) aadmi (mere human) nanaku (Nanak) vaichara (poor).' (SGGS, Mehl 1, 991)

Guru Nanak's antipathy was against the suspicions practiced blindly under various traditions and cultures. In figure 9, Guru Nanak is in white, the symbol of divine purity, on which the dyes of shallow and meaningless traditions and rituals cannot influence, who knows, God is One and Formless and the Creator of infinite universe.

Guru Nanak was about thirty when he was conferred as Guru. 'Nanak being conferred with guruship within the fecund waters of the River Bein. Nanak disappears in the river for three days, during which he is given a cup of ambrosia and is asked to recite the divine name. Having experienced the ontological oneness, Nanak is then charged to deliver his revelation. The sacra or physical object that marks his special dispensation is the sirpao-the robe of honor bestowed on him from the divine court-sirpao baba dargaho milia. But Nanak received it after he passed his divine examination. As the Janamsakhi narrates, Nanak recited beautiful poetry in praise of the One, which became the matrix for the Guru Granth.' (Kaur Singh 2004, 291). So Nanak always shown with a sir-o-pau (head to foot), a long unstiched fabric used as a wrap. The illustrators of Janamsakhis often portray Guru Nanak in simple with divine wrape.

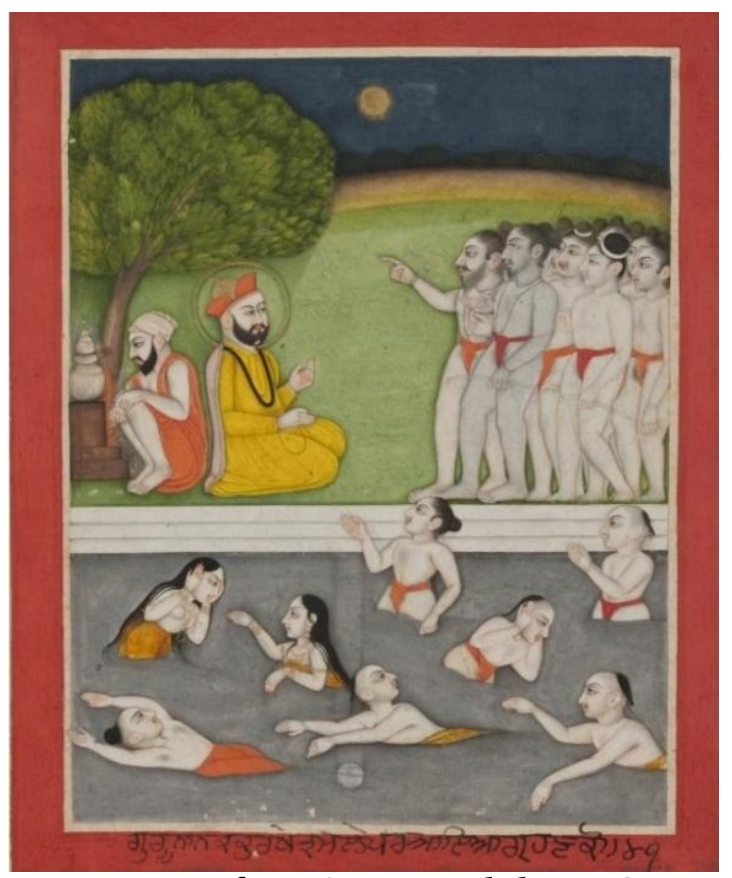

Figure 10. Guru Nanak encounters a group of ascetics at Kurukshetra. C.1755-177o. Probably Murshidabad, West Bengal state. Object ID: 1998.58.37. Asian Art Museum. Source:

http://searchcollection.asianart.org/view/objects/asitem/73/45/title-asc/designationasc?t:state:flow=bf5744f8-ebf3-4ce4-ad28-7fd948doeb2b

There is no denial that as per Gurbani no particular day is auspicious or inauspicious. At Kurukshetra, on the occasion of solar eclipse and festival, devotees and Brahman ascetics aggressively criticized Guru Nanak for cooking food, as it is prohibited during eclipse. Nanak's reply to his critics, not only highlighted their double standards in certain matters of faith but also 
expressed Nanak's own teachings. Fifth Guru advances the philosophy of Guru Nanak, 'Har har naam (name) majan (cleansing bath) kar sucche (purified). Koti (millions) grahan (solar eclipse) punn phal muche (reward surpasses the giving of charity)' (SGGS, Mehl 5, 197). 'Teerath tap da-i-aa dat daan, Jay ko paavai til kaa maan.' (SGGS, 4)

Guru Nanak was against the division of castes prevailing vastely in the contemporary society. Tarkhan or carpenter bhai (brother) Lalo (figure 11) lived near Emnabad in Punjab is a representater of low caste society with whom Guru Nanak and Mardana stayed for a month. The meeting of high caste Bedi Guru Nanak with low caste carpenter bhai Lalo is a rejection of the Hindu philosophy of varna pratha (caste- system) and untouchability. Simultaneously, it also depicts the contemporary social structure and the clashes prevailing among low and high classes of society. Guru Nanak's philosophy of 'Equality of Human being' is popularly visualized by the illustrators with as simplicity and chastity as was the relation of Guru Nanak with bhai Lalo, his companion of earlier births. Bhai Lalo always remains busy with his tools in his courtyard conversing with guru. 'The quiet exchanges between the Guru and the simple low-caste carpenter are in focus here. While Mardana plays upon his instrument, the Guru seems to hold forth, Lalo listens to every word, every single verse with care but does not stop working. Honest labor, and the fruit thereof, is what the painter seems to be intent upon driving home.' (Goswamy and Smith 2006, 54)

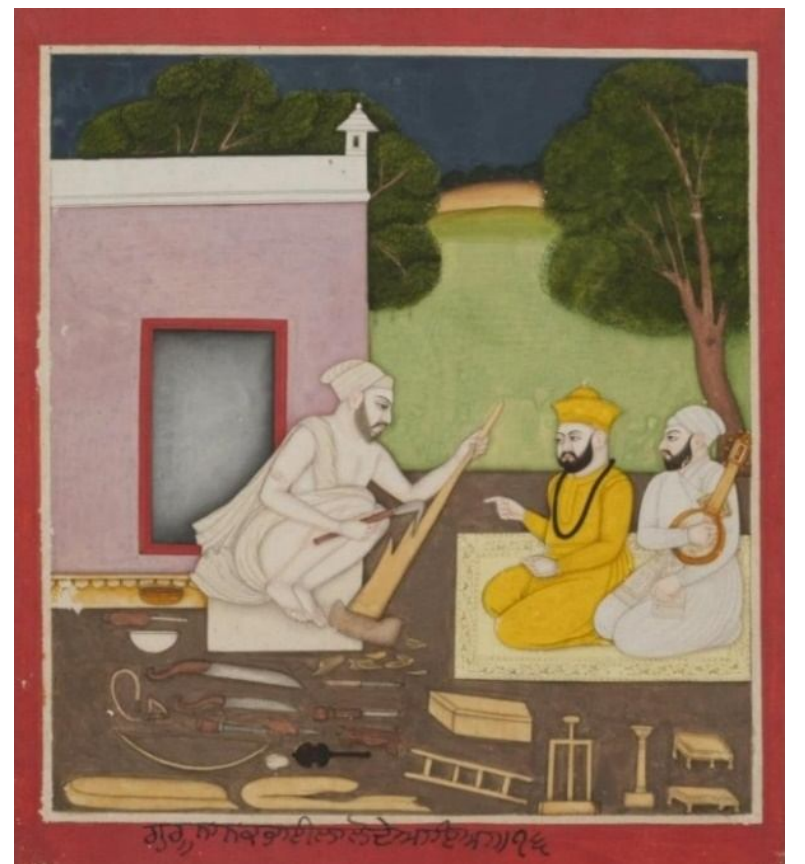

Figure 11. Guru Nanak's visit to Bhai Lalo the carpenter. C. 1755-1770. Probably Murshidabad, West Bengal state. Object ID: 1998.58.14. Asian Art Museum. Source:

http://searchcollection.asianart.org/view/objects/asitem/search@/10?t:state:flow=075bocbf-3odb-4fga-bdo1babg6d2e4acf

His philosphy was 'None is Hindu, none is Muslim'. He spread the message of equality to associate two castes which were divided among various sub-castes. 'Everyone- king and trader, sannyasi and mullah, besides Guru Nanak himself and his companion, Mardana, of courseremains in character, and one gets a sense of meanings unfolding, layers being uncovered.' (Goswamy 2006, 15) 


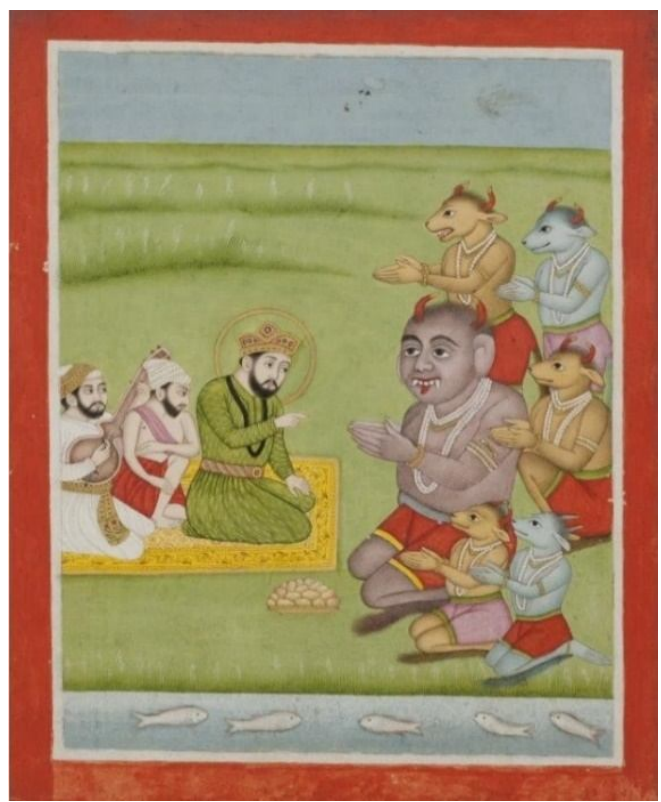

Figure 12. Guru Nanak's meeting with Dev Loot and other demons. C. 18oo-1850. probably Murshidabad, West Bengal state. Object ID: 1998.58.20. Asian Art Museum. Source:

http://searchcollection.asianart.org/view/objects/asitem/73/59/title-asc/designationasc?t:state:flow $=7$ fi53a6c-974c-4841-9aob-6b7432b87441

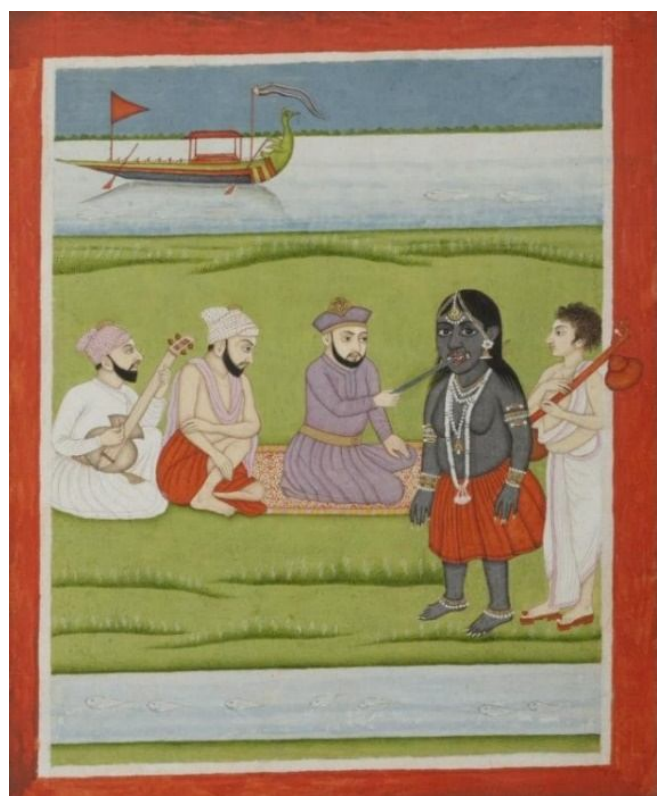

Figure 13. Guru Nanak's meeting with the demon Kaliyuga. C. 180o-1850. Probably Murshidabad, West Bengal state. Object ID: 1998.58.18. Asian Art Museum. Source:

http://searchcollection.asianart.org/view/objects/asitem/73/66/title-asc/designationasc?t:state:flow=8a441399-b28d-4400-842f-a8fdd 5 f88137

It was not new to travel on feet or by water to seek the world in those days by the adventurers of the whole world. Guru Nanak's contemporary travelers Columbus, Vasco da Gama and other Sufis pirs travelled much. But Guru Nanak was the most travelled person of his time. Guru Nanak during his first travel stayed with tribal people (vanmanush) for one month. Guru Nanak incarnated on this mortal land to emancipate its creatures, whoever, human beings, 
animals, birds, mystics; who encountered the Guru, became liberal. He emancipated not only the creatures of this world (ehlok) but also of the other world (perlok). In figure 11, He is conveying the godly message to bhai Lalo but in figure 12, tribal people are serving him.

There are very popular stories in Hinduism, which examines purity of heart and devotion of many sages in which one is of sage Vishvamitra and Menaka. In figure 13, on an island surrounded by water, Kaliyuga and Narada came to examine the immensity of Guru Nanak like the temptation of demon Mara to examine the purity of Buddha. After examining the immensity of Guru Nanak, Kaliyuga and Narada, both acknowledged his superiority. A blank boat with peacock mouth in the background is like a divine means to go from earth (ehlok) to another world (perlok or heaven) or to cross 'Bhavsagar'. 'Nanak bedi sach ki (boat of truth) tareeye (ferry) gur veechar (contemplate the guru). Eki aavahi (some come) ek javahi (some go) puri bhare ahankar (entirely filled with selfishness).' (SGGS, Mehl 1, 20). Guru Nanak in purple coloured garb is like an emperor, in front of whom Kaliyuga in black appears dwarf, while Narada in white contrasting Kaliyuga.

A variety of ethnic diversity is represented by the illustrators in the form of contemporay identities, along with changing appreances of the Guru. 'Spectators are urged to read it closely.' (Kaur Singh 2013, 34). Guru's yellow or saffron garb is a symbol of light and knowledge in Hindu culture. '...the outlandish garb that Nanak wore on his journeys, it was always a combination of styles worn by Hindu Sadhus and Muslim fakirs.' (Singh 2004, 34). Although Guru Nanak used to change his garb according to the culture of community wherever he visited, to unify with the diverse populace. To indicate his followers from two societies, illustrators portrayed him in Hindu- Muslim dresses while during Babur's period, 'A Hindu buttoned his coat to the right, a Muslim to the left. ..... The favourite colour of Hindus was red and yellow, and of the Muslims blue and green. Muslims would not wear red.' (Gupta 1984, 37). A garb embroidered with Quranic verses was gifted to him by the king of Baghdad during his visit is preserved even today at the Gurudwara of Nankana Sahib at Sheikhupura district of Pakistan. (Khan Mohammad 1962, 22). But in Janamsakhi illustrations, a variety of garbs is used to convey different messages. The bright golden coloured precious dress (figures 6-7) of young Nanak in wedding ceremony changes time to time acccording to the incident. Saffron, yellow, white or green colours of his robes are the symbol of his ascetic nature and disinterest in the worldly pleasures while purple (figure 13) a royal colour signifies his victory over Kaliyuga, in front of whom, he remains an ascetic, not a ousehold.

Guru Nanak also visited Muslim countries during his fourth travel. Figure 14 is the representation of Guru Nanak's encounter with muslim piligrims and fakirs on the way to the deserted land of Mecca, where non- Muslims were not allowed to enter. Baba Nanak and Mardana leave their company as the Sayyid rulers killed the Hindu piligrims. But Guru Nanak went Mecca in Muslim attire. 'Baba phir mecca gaya (Baba went Mecca) neel baster (blue attires) dhare (put on) banvari (1-32-1). Asa (stick) hath (hand) kitab (book) kacch (armpit) kooja bang (metal pot) musalla (rug) dhari (1-32-2)5 (Donning blue attire then Baba Nanak went to Mecca. He held a stick in his hand, pressed a book under his armpit, caught hold of a metal pot and mattress.). Guru Nanak appears creates a link between Hindu and Muslim philosophy. Mardana, his life time companion, was a Muslim, but his depiction in saffron is very common while Sufis wear blue. In figure 14, Guru Nanak's blue coloured attire and saffron turban is also a symbolic representation of 'Hindu ka guru, musalmaan ka peer'. While Mardana and hajis are also shown under Guru Nanak's influence in saffron coloured turbans. Simultaneously, the deserted land of Mecca 
appears full blossom after touching the feet of guru, while a big tree to shade Guru is a symbol of chatra from Hindu philosophy.

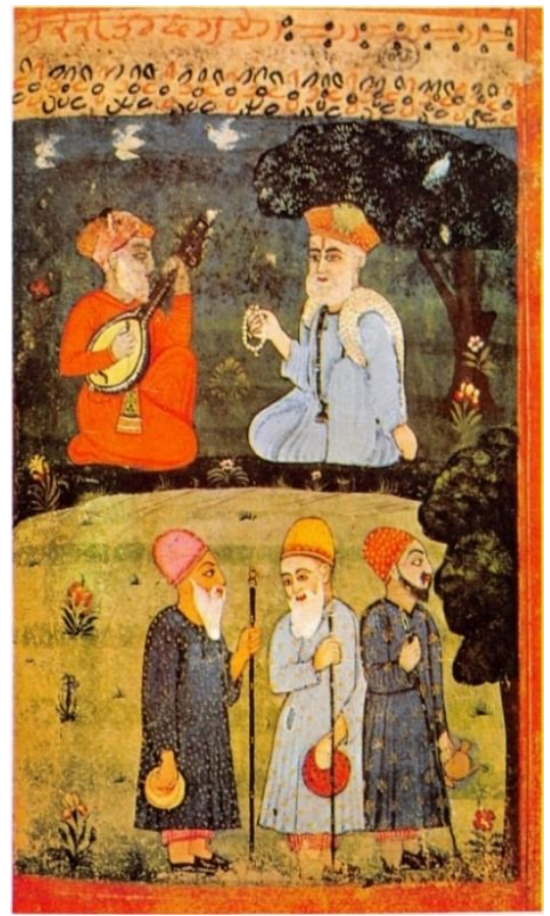

Figure 14. Baba Nanak and Mardana with Fakirs on their way to Mecca. 1733. B-4o Janamsakhi. India Office Library. Source: Hans, Surjit. Ed. 1987. B-4o Janamsakhi Guru Baba Nanak paintings. Amritsar: Guru Nanak Dev University. Plate: 30 )

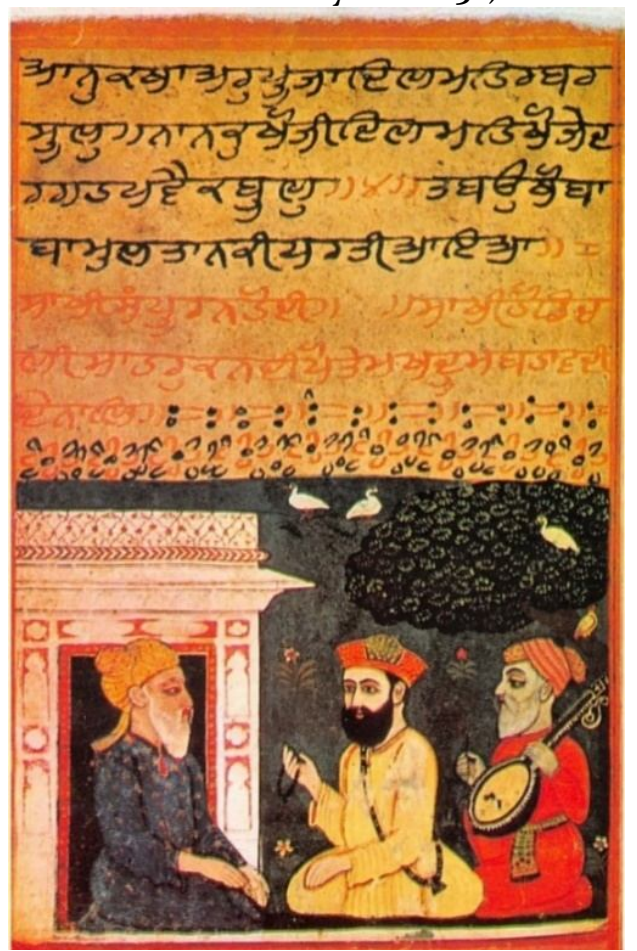

Figure 15. Shaikh Rukn-ud-Din, Baba Nanak and Mardana. 1733. B-4o Janamsakhi. India Office Library. Source: Hans, Surjit. Ed. 1987. B-4o Janamsakhi Guru Baba Nanak paintings. Amritsar: Guru Nanak Dev University. Plate: 13) 
Guru Nanak's physic also changes with the period and illustrators of various schools grasped and perceived and visualised the changes in appearance and personality of the guru. The illustrator portrayed him as an old person of about 50 years with white beard and blue dress as Sufi saint but there is absence of staff and book in his hands who coaxes the Muslim saint Shah Sharaf and haji fakirs saying that, 'Balla vaat na jogia pairi jog na pandh. Tithe akal na apde jithe pariya di sandh'. Guru Nanak wore blue Sufi garb in Mecca. A full blossomed tree as a chatra always shades him during his various travels, wherever at Mecca, Madina, Kurukshetra or Himalaya. In figure 15, while conversing with Shaikh Rukn-ud-din, Guru Nanak appears in his yellow garb as his legitimacy revealed in front of Shaikh who is sitting against black. Guru Nanak spoke verses on the Koranic pattern expressing Sikh doctrines to Shaikh Rukn-ud-din and others like Peer Bahabuddin Gaus Soora, Peer Zalal-din Soora. Sayyad Karimdeen, Haji Rattan, Shaikh Ibrahim, Shaikh Kamal, who accepted the sovereignty of Baba Nanak Shah fakir, which can be seen in the form of relics of Guru Nanak at Mecca. It is instructed in Guru Granth Sahib that namaz or Muslim prayer should be practiced seventeen times by a true Muslim and on the other hand, Hindus are also asked to have firm faith in their religion, which is the best example of universal philosophy of secularism as well as multiculturalism, where Hindus and Muslims are equal.

Recent researches shows that Guru Nanak also visited Grecce, Istanbul-Turkey, Israel, Palestine and Syria (Chahal 2006, 2), along with Iran, Iraque, Mecca and Madina etc., where he spread his philosphy of equality. When Guru Nanak rejects castesism saying that, 'Na koi Hindu, na koi Musalmaan', he also emphasis his philosophy of humanity stressing the belief of oneness of God. He utters in his bani, 'Ek Onkar, Sat naam' (SGGS, 1) God is one and his name is ture in the world. Universal concept of God is followed by Guru Nanak. Kudrat (nature) nurtures all the human being in the same way without any distinction. In arti, he utteres at Jagannath in sixteenth century, 'Gagan (sky) mein thaal (platter) rav (sun) chand (moon) dipak (lamps) bane, tarika mandal (stars) janak moti (pearls), dhoop (Incense) malyanlo (fragrance) pavan (wind) chavro (swaying) kare sagal banrai (entire forestry) phulant joti, kaisi arti hoye (what a beautiful aarti) bhav khandna (destroyer of fear) teri arti. Anhada Shabad (unstruck sound of words, bani) Vajanta bheree (rhythm of drums)' '.....the complete Arti that is sung today has in reality been composed by two Gurus, a cobbler, a barber, a weaver and a farmer, all from humble stock. This is proof enough that Sikhism believes in the equality of all humankind (Dhir 2012, 5)

When we contemplate and ruminate the sacred Sikh scripture 'Shri Guru Granth Sahib', we perceive a unique composition comprising an infinite universe in it created by secularism as well as multiculturalism. But from where this universality came? Although Guru Nanak born in Hindu family cultivated with Hindu philosophy, but the universality of Sikh scripture begins with the travels of Guru Nanak to seek the truth of God among various cultures. Jains, Hindus, Muslims, Pirs, Sufis, Siddhas, Turks, Gorakhs etc. created a world of multi-culture around Guru Nanak, where Guru Nanak perceived their cultures and religions and sowed the seeds of a new crop of Sikhism on the land of Punjab and the crop grew and ripe among his shishyas (followers) with the philosophy of Guru Gobind Singh, penned in his Dasam Granth, "Kou bhaiyo mundiya saniyasi koi jogi bhayo, koi bhrahmachari koi jati anmaanavo, Hindu turak ko-u raafji, imam saafi, maanas ki jaat sabh-a ek-i pahichanabo." [16 / 89]. With the spread of Sikhism through the nine successors of Guru Nanak, Sikhism became a leading religion and culture of the populace of Punjab along with prevailing dominant cultures of Hinduism and Islam. Sufism of north merged with the Bhaktism of south which reflect precisely in the great composition of Sikhism. A unique, stable and firm conversion of religion as well as culture was generated through the philosophy of Sikhism which granted the Hindu Jat populace a firmness of ideas to fight against unsteady fanatic atmosphere. 
The glimpse of multi-cultures around Guru Nanak was depicted through the illustrations of Guru Nanak's Janamsakhis. A world of contemporary ethnic variation is created in these illustrations through the hands of Janamsakhi illustrators of various castes, because, 'The artists who painted him were also Hindu, Muslim, Buddhist, or Jain, and they presented the Sikh Guru through the lens of their respective religious beliefs.' (Kaur Singh 2013, 32)

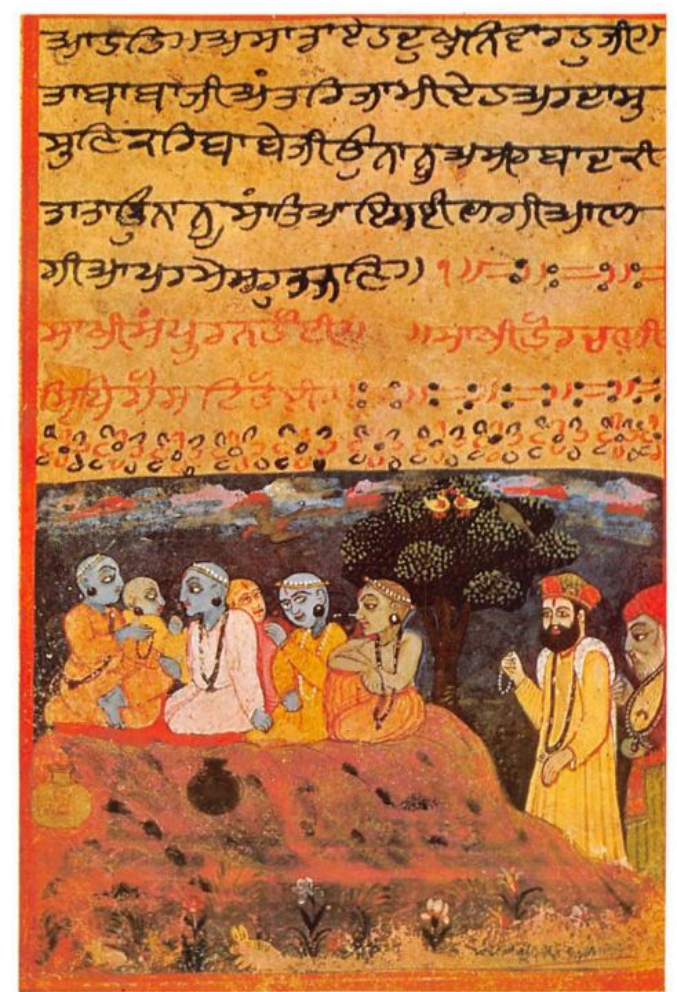

Figure 16. Baba Nanak and Mardana come upon the Siddhas on the Sumer Mountain. 1733. B-4o Janamsakhi. India Office Library. (Source: Hans, Surjit. Ed. 1987. B-4o Janamsakhi Guru Baba Nanak paintings. Amritsar: Guru Nanak Dev University. Plate: 2o)

Guru Nanak met Siddhas, when they were sitting on Sumer Mountain. 'Sidh sabha (meeting of Sidhas) kar aasan baithay (sitting in the Yogic stances) sant sabhaa jaikaaro'. (SGGS, Mehl 1, 938). He trying to teach them that, 'darsan bhaikh (Wearing the robes of Yogis) karahu jog indra mundraa (put on the ear-rings) jholi khinthaa (begging wallet and patched coat)' (SGGS, Mehl 1, 939). The illustrator of B-40, grasp the sakhi and philosophy secreted in it. In figure 19, kanfat, Sidhas with black coloured earrings are conversing on a mountain wearing saffron robes. Some of them smeared their bodies with the ashes. Guru Nanak's message is for them, 'Kis karan grihu tajiyo udasi. Kis karan ehu bhekh nivasi.'(SGGS, Mehl 1, 939)

In figure 17 , he is trying to Mullah that God is one and is everywhere. 'Telling the mullah not to be perplexed, Nanak simply said: "The Ka'aba is still where it was; it is only the curtain of your ignorance which has been removed. The Ka'aba is only a house of worship, but God is everywhere, Allah is everywhere. The greatest miracle is His omnipresence." (Goswamy and Smith 2006, 86). In figure 17, Guru Nanak is lying in front of an old Islamic architecture with three domes and two minarets. His blue attire replacing the saffron robe is also trying to say that he entered in Mecca as a sufi pir but did not lose his own identity in the form of saffron turban. Mardana in saffron clad also appears freeze to see the Guru's magnitude. 


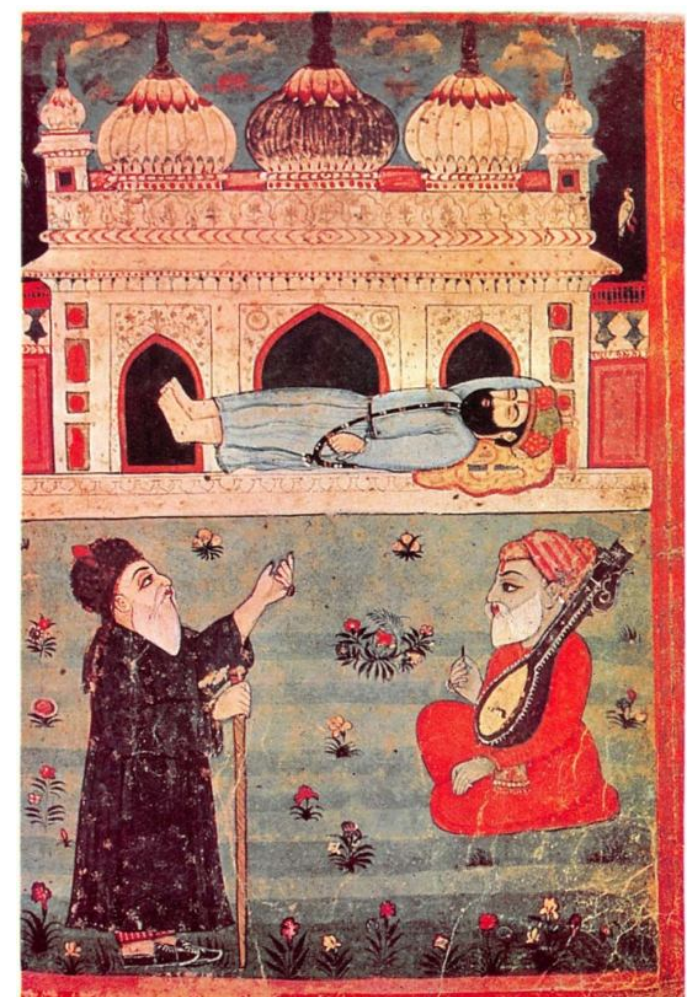

Figure 17. Baba Nanak at Mecca with Mulla and Mardana. 1733. B-4o Janamsakhi. India Office Library. (Source: Hans, Surjit. Ed. 1987. B-4o Janamsakhi Guru Baba Nanak paintings. Amritsar: Guru Nanak Dev University. Plate: 12)

Jap ji or the Morning Prayer is a composition pronounced by Guru Nanak which reveals his experiences and philosophy about different cultures as well as religions. 'Asankh bhagat gun gi-aan veechaar, Asankh satee asankh daataar, Asankh soor muh bhakh saar, Asankh mon liv laa-i taar, Kudrat kavan kahaa vichaar'. (SGGS, 4). The evil circumstances prevailed in contemporary society are also precise in the verses of Nanak. 'Asankh moorakh andh ghor. Asankh chor haraamkhor. Asankh amar kar jaahi jor. Asankh galavadh hati-aa kamahi. Asankh paapee paap kar jaahi. Asankh koorhi-aar koorhay firaahi. Asankh malaychh mal bhakh khaahi. Asankh nin-dak sir karahi bhaar. Naanak neech kahai vichaar.' (SGGS, 4) 'In his encounters, there is no impulse to convert, and there is no acrimony toward other religious leaders.' (Kaur Singh, 2013, 40)

Guru Nanak's bani (Hymns) descibes the prevailing variation of social, religious, political circumstances and their philosophical concepts precisely. Nanak was in the Punjab, when the Mughal emperor Babur (reigned 1526-1530) attacked the city of Saidpur (now Emnabad, Pakistan). Babur was highly impressed to see the miracle of Guru Nanak as other prisoners were grinding grain by hand at the time (figure 18), but Nanak's millstone works by itself. 


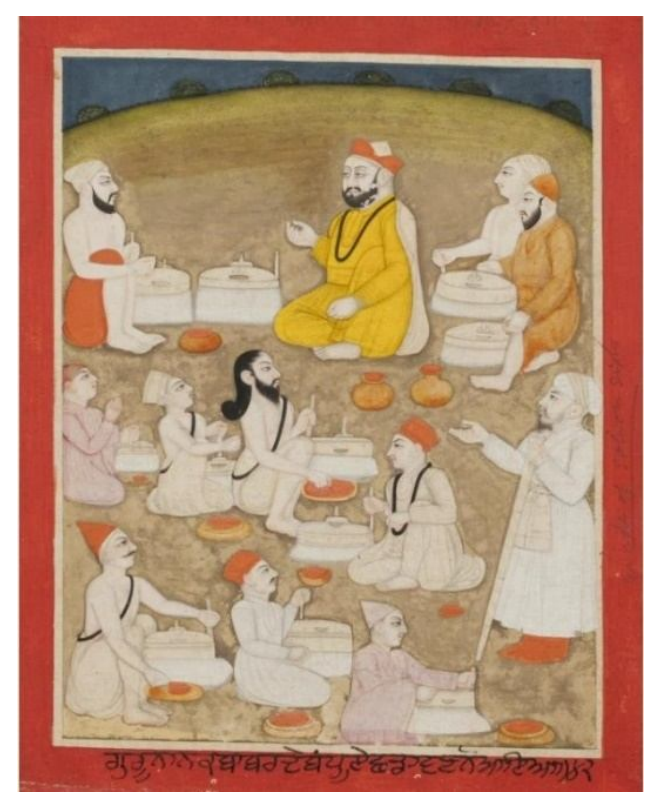

Figure 18. The Mughal emperor Babur, visiting Guru Nanak in prison, witnesses the miraculous self-turning millstone. C. 1750-18oo. Probably Murshidabad, West Bengal state. Object ID: 1998.58.39. Asian Art Museum. Source:http://searchcollection.asianart.org/view/objects/asitem/73/168/title-asc/designationasc?t:state:flow=3ao6o472-6dco-46fa-8gfc-82ffd $774 \mathrm{~d}_{4} 62$

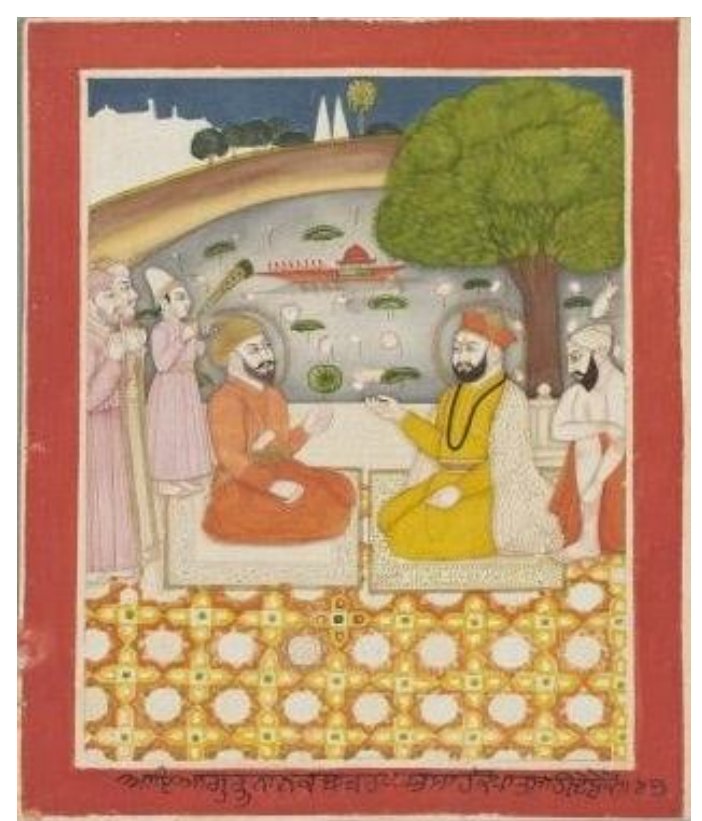

Figure 19. Guru Nanak talks with the Mughal emperor Babur. C. 1755-1770. Probably Murshidabad, West Bengal state. Object ID: 1998.58.38. Asian Art Museum. Source:

http://searchcollection.asianart.org/view/objects/asitem/73/54/title-asc/designationasc?t:state:flow=7fi53a6c-974c-4841-9aob-6b7432b87441

The emperor releases Nanak and other prisoners (figure 19). Emperor himself appears in saffron influenced with Guru's philosphy and personality. Guru Nanak describes his experiences in Baburvani 'Khurasan khusmana keeya (having attacked Khuraasaan) hindustan daraya (terrified Hindustan)'(SGGS, Mehl 1, 360). 'There is a companion painting depicting the unusal events inside the prison; here the Guru is shown conversing with Babur. The painter renders what can be 
called a generic scene- meeting between two notables on the trrace of mansion- but the import of it is clear to the viewer. Guru Nanak is recognised at once.' (Goswamy and Smith 2006, 94). On the riverbank, the meeting of a divine person with Muslim emperor, where emperor also influenced with the divine personality and illustrator visualized this feeling by saffron attires of a Muslim person. A boat in the lotus pool also depicts the mental status of emperor. Prosperous status of emperor is clear as he is seated on a carpet with his attendents while the heavenly Guru is also seated with his earthly companion, Mardana in a pleasant atmosphere.

There is much to write but I conclude with the lines that Janamsakhi illustrations are one of the best source to know the life of Guru Nanak and his philosophy as well as identifying different cultures created through the hands of various illustrators. Guru Nanak never believed in the plurality of God but welcomed and accepted plurality of society and its cultures and religions, which was attempted to write by the Janamsakhi illustrators in the medium of lines, colours and emotions on the miniature surfaces with their own perceptions.

\section{Notes}

${ }^{1}$ Kaur Singh (2013). See footnotes on pg. 32. Nikky met Sardar Sikandar Singh Bagharian to see the manuscript in Chandigarh on July 17, 2011.

${ }^{2}$ Singh (2004). See footnotes on pg. 57

3 The miraculous life of Baba Siri Chand ji, Loving son and true follower, of Guru Nanak Dev ji. New Delhi: Sterling Press Private Limited. 3.

${ }^{4}$ The miraculous life of Baba Siri Chand ji, Loving son and true follower, of Guru Nanak Dev ji. New Delhi: Sterling Press Private Limited. See pg. 5.

${ }^{5}$ Gurdas. Vaaraan.

${ }^{6}$ Sri Guru Granth Sahib. Raga Dhanasari Mahalla 1. Aung 13. Also see Dhir (2012)

\section{References}

Archer, W. G. (1960). Indian Miniatures. New York Graphic society.

Chahal, Devinder Singh. (2006). "Monument of Guru Nanak in Istanbul, Turkey, A new discovery." Understanding Sikhism, The Research Journal. (October): 1- 6

Chaitanya, Krishna. (1994). A History of Indian Painting: The modern period. New Delhi: Abhinav publications.

Dhir, Anil. (2012). "The Jagannath Temple and the Sikh Arti." Odisha Review. (March): 1-6

Hans, Surjit. (1987). B-40 Janamsakhi Guru Baba Nanak paintings. (Ed.), Amritsar: Guru Nanak Dev University.

Goswamy, B. N. (2000). Piety and Splendour-Sikh heritage in art. New Delhi: National Museum.

Goswamy, B.N. and Smith Caron. 2006. I see no stranger Early Sikh art and devotion. Mapin Publishing Pvt. Ltd.

Gupta, Hari Ram. (1984). History of the Sikhs. Vol. I, The Sikh Gurus 1469-1708. New Delhi: Munshiram Manoharlal Publishers Pvt. Ltd.

Kaur Singh, Nikky Guninder. (2004). "Sacred Fabric and Sacred Stitches: The Underwear of the Khalsa". History of Religions, Vol. 43, No. 4. (May): 284-302

Kaur Singh, Nikky Guninder. (2013). "Metaphysics: Guru Nanak in Early Sikh Art.” History of Religions, Vol. 53, No. 1. (August): 28- 65

Khan Mohammad, Waliullah Khan. (1962). Sikh shrines in West Pakistan. Pakistan: Department of archaeology, Ministry of Education and Information, Government of Pakistan.

Singh, Kirpal Singh. (2004). Janamsakhi tradition- an analytical study. Amritsar: Singh Brother.

Singh, Khushwant. (2004). A history of the Sikhs. Vol. I: 1469-1838. Oxford University Press.

Stronge, Susan. (1999). The Arts of the Sikh Kingdoms. (Ed.), New Delhi: Prakash Books. 